\title{
PENGARUH PENGUNGKAPAN PROGRAM CORPORATE SOCIAL RESPONSIBILITY TERHADAP PROFITABILITAS PERUSAHAAN
}

\author{
Nur Salina \\ Dwi Kartikasari, S.T., M.B.A. \\ Prodi Administrasi Bisnis Terapan \\ Politeknik Negeri Batam \\ *Corresponding author. Tel/HP: 0857-6541-1770; \\ Email: nursallyna@gmail.com
}

\begin{abstract}
Abstrak
Penelitian ini bertujuan untuk mengetahui hubungan antara item-item di dalam pengungkapan Corporate Social Responsibility (CSR) terhadap profitabilitas perusahaan yang diukur menlalui Return On Assets dan Net Profit Margin. Metode analisis data yang digunakan pada penelitian ini adalah regresi data panel. Data yang digunakan dalam penelitian ini yaitu data sekunder dengan menganalisis laporan tahunan dan laporan keuangan perusahaan pada tahun 2014 dan 2015. Hasil penelitian menunjukkan bahwa hanya terdapat satu item CSR yang memiliki pengaruh yang signifikan terhadap Return On Assets (ROA) yaitu indikator masyarakat sosial. Sementara untuk variabel NPM hanya terdapat indikator kinerja lingkungan yang memiliki pengaruh yang signifikan terhadap Net Profit Margin (NPM).
\end{abstract}

Kata kunci: Corporate Social Responsibility, Net Profit Margin, Profitabilitas Perusahaan, Regresi Data Panel, Return On Asset.

\begin{abstract}
This study aims to determine the relationship between items in the disclosure of Corporate Social Responsibility (CSR) to profitability The company measured through Return On Assets and Net Profit Margin. Data analysis method used in this research is data panel regression. Data used in this research is secondary data by analyzing annual report and company financial report in 2014 and 2015. The result of research indicate that there is only one item of CSR that have significant influence Against Return On Assets (ROA) is an indicator of social society. While for the NPM variable there are only environmental performance indicators that have a significant influence on Net Profit Margin (NPM).
\end{abstract}

Keywords: Corporate Social Responsibility, Data Panel Regression, Net Profit Margin, Profitability, Return On Asset. 


\section{PENDAHULUAN}

Perusahaan sejatinya memiliki limbah yang ditimbulkan dari proses produksi. Limbah dari output perusahaan tersebut bisa menyebabkan dampak negatif bagi lingkungan, diantaranya polusi udara, polusi sungai, dan lain sebagainya. Mengutip dari kasus lumpur panas Lapindo Berantas Inc., di Sidoarjo, Jawa Timur, Indonesia adalah contoh bahwa apapun kegiatan produksi perusahaan ditambah dengan ambisi mengejar keuntungan yang sebesar-besarnya akan berdampak bagi lingkungan sekitar dalam jangka waktu tertentu. Akibatnya, perusahaan harus mengeluarkan cost tambahan untuk menanggulangi pencemaran lingkungan yang berujung pada bencana alam tersebut. Dalam hal ini, muncul pula suatu kesadaran menjaga lingkungan dan mengurangi limbah pencemaran lingkungan dari kegiatan produksi perusahaan. Banyak perusahaan mulai mengembangkan tindakan tanggung jawab sosial perusahaan terhadap masyarakat. Bentuk pertanggungjawaban sosial perusahaan ini dikenal dengan istilah Corporate Social Responsibility.

Corporate Social Responsibility atau pertanggungjawaban sosial perusahaan tidak hanya tindakan yang dilakukan perusahaan kepada lingkungan, tetapi juga kepada masyarakat, tenaga kerja perusahaan, pelanggan, dan lain sebagainya. Definisi CSR secara universal menurut The World Business Council for Sustainable Development yaitu Corporate Social Responsibility sebagai suatu komitmen bisnis untuk berkontribusi dalam pembangunan ekonomi berkelanjutan, bekerja dengan karyawan perusahaan, keluarga karyawan tersebut, berikut komunitas setempat (lokal) dan masyarakat secara keseluruhan dalam rangka mengingkatkan kualitas hidup. Banyak penelitian menemukan terdapat hubungan positif antara tanggung jawab sosial perusahaan (Corporate Soial Responsibility) dengan kinerja keuangan, maupun dampaknya dalam jangka panjang. Pengimplementasian program CSR merupakan kegiatan yang tidak lagi dianggap sebagai beban ataupun biaya bagi perusahaan namun juga dianggap sebagai investasi.

Berlandaskan kepada peraturan Undang-Undang No. 47 tahun 2007 pasal 74 tentang Perseroan Terbatas dan Undang-Undang No. 25 tahun 2007 pasal $15 \mathrm{~b}$ dan pasal $16 \mathrm{~d}$ tentang Penanaman Modal, yaitu setiap perseroan atau penanaman modal diwajibkan untuk melakukan sebuah upaya pelaksanaan tanggung jawab sosial perusahaan yang telah dianggarkan dan diperhitungkan sebagai biaya perseroan. Termasuk perusahaan akan dikenakan sanksi apabila tidak mengikuti kebijakan yang telah diatur dalam undang-undang tersebut. Dalam hal ini, BUMN selaku perusahaan yang modal usahanya berasal dari pemerintah wajib memberi contoh kepada perusahaan lain untuk lebih mengedepankan tanggung jawab sosialnya terhadap masyarakat dan lingkungan sekitar. BUMN merupakan perusahaan milik pemerintah yang saat ini memiliki 14 sektor. Adanya BUMN merupakan aset penting Indonesia dalam membentuk perekonomian nasional yang berperan mewujudkan kesejahteraan masyarakat. Untuk itu, penulis memiliki ketertarikan untuk meneliti sejauh mana implementasi program Corporate Social Responsibility di perusahaan milik negara (BUMN) dan pengaruhnya terhadap profitabilitas masing-masing perusahaan tersebut, maka terbentuklah penelitian yang berjudulkan "Pengaruh Pengungkapan Program Corporate Social Responsibility (CSR) terhadap Profitabilitas Perusahaan".

\section{KAJIAN PUSTAKA}

Murtaza, Akhtar, Ijaz, dan Sadiqa (2014) meneliti mengenai Impact of Corporate Social Responsibility on Firm Financial Performance: A Case Study of Pakistan. Variabel yang dianalisis dalam penelitiannya adalah CSR sebagai variabel independen dan manfaat perusahaan sebagai variabel dependen. Nvivo test 
digunakan dalam analisis kualitatif. Kesimpulan yang didapat dari penelitian tersebut adalah CSR dan Finance Performance memiliki hubungan yang positif.

Pramana dan Yadnyana (2016) meneliti mengenai Pengaruh Corporate Social Responsibility pada Kinerja Perusahaan Manufaktur dengan memiliki 55 sampel dan menggunakan analisis regresi linear sederhana sebagai alat analisis menyimpulkan bahwa pengungkapan CSR berpengaruh secara positif dan signifikan terhadap kinerja keuangan perusahaan dan kinerja pasar perusahaan.

Selanjutnya Wulandari, Ramantha, dan Wirakusuma (2016) meneliti mengenai Dampak Moderasi Profitabilitas terhadap Pengaruh Corporate Social Responsibility pada Nilai Perusahaan Manufaktur. Dengan sampel sebanyak 37 perusahaan manufaktur dan menggunakan uji asumsi klasi dan uji kelayakan model serta menggunakan uji Moderated Regression Analysis sebagai alat ukur variabel pemoderasi. Hasil dari penelitian tersebut adalah diketahui bahwa CSR berpengaruh secara positif terhadap nilai perusahaan manufaktur dan CSR terbukti mampu memperkuat hubungan antara pengungkapan CSR dengan nilai perusahaan manufaktur.

Serta pada tahun 2015 sebuah jurnal berjudulkan Pengaruh Pengungkapan Corporate Social Responsibility pada Nilai Perusahaan dengan Profitabilitas sebagai Pemoderasi oleh Putra dan Wirakusuma (2015). Sampel yang dimiliki adalah sebanyak 26 perusahaan pertambangan yang diambil berdasarkan metode probability sampling. Teknik analisis yang digunakan adalah menggunakan regresi linear sederhana dan analisis regresi moderasi. Hasil penelitian menunjukkan bahwa CSR berpengaruh positif terhadap nilai perusahaan dan profitabilitas mampu memperkuat hubungan CSR pada nilai perusahaan.
Dan artikel berjudulkan Pengaruh Pengungkapan Corporate Social Responsibility (CSR) terhadap Profitabilitas Perusahaan oleh Multafia Almar, Rima Rachmawati, dan Asfia Murni pada tahun 2012 dengan menggunakan analisis regresi linear tunggal sebagai alat analisis menunjukkan bahwa adanya hubungan yang positif dan signifikan antara pengungkapan CSR dengan profitabilitas perusahaan.

\section{CORPORATE SOCIAL RESPONSIBILITY}

Menurut Rudito (2013), Corporate Social Responsibility pada dasarnya adalah sebuah kebutuhan bagi perusahaan untuk dapat berinteraksi atau berhubungan langsung dengan komunitas lokal sebagai bentuk masyarakat secara keseluruhan.

CSR menurut Global Reporting Initiative memiliki enam kategori diantaranya kinerja ekonomi, kinerja lingkungan, ketenagakerjaan, hak asasi manusia, masyarakat sosial, dan tanggung jawab produk. Masing-masing kategori memiliki item-item yang secara keseluruhan jumlah item pada pengungkapan CSR terdapat 65-78 item.

Pertama, untuk mendapatkan data CSR perlu dilakukannya analisis laporan tahunan perusahaan. Item CSR yang diungkapkan pada laporan tahunan perusahaan diberi skor 1 dan untuk CSR yang itemnya tidak diungkapkan perusahaan pada laporan keuangannya diberi skor 0 .

Kedua, item-item yang telah terkumpul dilakukan perhitungan untuk mendapatkan nilai CSR Index nya dengan menggunakan rumus total item yang diperoleh dibagi dengan total item secara keseluruhan.

Selanjutnya untuk mengukur profitabilitas perusahaan peneliti menggunakan ROA dan NPM sebagai rasio profitabilitas yang dianggap mempunyai hubungan terhadap pengungkapan CSR. 


\section{PROFITABILITAS PERUSAHAAN}

Profitabilitas perusahaan merupakan usaha perusahaan untuk mendapatkan keuntungan dalam kurun waktu tertentu. Profitabilitas perusahaan adalah salah satu landasan penilaian yang mencerminkan keadaan/kondisi perusahaan. Dalam menilai kondisi tersebut dibutuhkan alatalat analisis serta dasar teori yang kuat. Alat-alat analisis yang dimaksud yaitu rasio-rasio keuangan (rasio profitabilitas). Menurut Samryn (2014), rasio profitabilitas merupakan suatu model analisis yang berupa perbandingan data keuangan sehingga informasi keuangan tersebut menjadi lebih berarti. Hasil pengukuran tersebut dapat dijadikan alat evaluasi kinerja manajemen perusahaan. Untuk perusahaan yang belum mencapai target finansial seperti yang telah ditentukan artinya mereka perlu memperbaiki lagi keefektifan dalam produktivitas kerja mereka.

\section{JENIS RASIO PROFITABILITAS}

Rasio profitabilitas memiliki enam jenis, diantaranya yaitu Gross Profit Margin, Return On Asset, Net Profit Margin, Return On Equity, Earning per Share, Devidend Payout Ratio. Namun pada penelitian kali ini peneliti hanya menggunakan rasio Return On Asset dan Net Profit Margin untuk mengukur hubungan pengungkapan program CSR dengan profitabilitas perusahaan.

\section{RETURN ON ASSET}

Menurut Harrison (2012), Return on Asset (ROA) merupakan salah satu rasio untuk mengukur keberhasilan suatu perusahaan dalam menggunakan asetnya untuk menghasilkan laba. CSR merupakan salah satu kegiatan yang perusahaan jalankan dalam mempergunakan asetnya untuk menghasilkan laba. Walaupun banyak biaya yang dikeluarkan dalam merealisasikannya, namun CSR diyakini sebagai usaha perusahaan dalam menciptakan laba jangka panjang. Laba yang dimaksud adalah investasi perusahaan berupa brand image yang positif pada mindset masyarakat. Untuk itu, rasio profitabilitas ROA dikatakan memiliki hubungan yang relevan dengan CSR. Berikut adalah rumus ROA:

$$
\text { ROA }=\frac{\text { Net Income }}{\text { Average Total Assets }}
$$

\section{NET PROFIT MARGIN}

Rasio profitabilitas Net Profit Margin (NPM) merupakan salah satu rasio yang memiliki kemampuan bagi perusahaan dalam menghasilkan laba yang diperoleh yang berasal dari hasil kegiatan operasional perusahaan tersebut. Kegiatan operasional perusahaan yang dimaksud yaitu salah satunya adalah kegiatan tanggung jawab sosial perusahaan (CSR). Semakin besar tingkat NPM perusahaan, maka semakin produktif perusahaan dalam menjalankan kegiatan operasionalnya. Hal ini menunjukkan bahwa NPM memiliki hubungan yang relevan terhadap CSR. Rumus dari NPM:

$$
N P M=\frac{\text { Net Profit }}{\text { Revenue }}
$$

\section{METODE PENELITIAN \\ Populasi dan Sampel}

Menurut Sugiyono (2012), populasi merupakan wilayah generalisasi yang terdiri dari objek atau subjek yang mempunyai kualitas dan karakteristik tertentu yang ditetapkan oleh peneliti untuk dipelajari dan kemudian ditarik kesimpulan. Gambaran dari populasi yang dijadikan objek dari penelitian ini adalah perusahaan BUMN.

BUMN adalah perusahaan yang modalnya berasal dari negara baik itu sebagian maupun seluruhnya. Keberadaannya sangat penting bagi tonggak perekonomian Indonesia. Meski modalnya berasal dari pemerintah, tidak menutup kemungkinan bahwa BUMN juga merupakan perusahaan profit. Dalam 
menerapkan program CSR, tidak sedikit perusahaan BUMN yang mengalami kerugian, akibat dari kerugian tersebut berdampak pada asset negara. Banyak program CSR yang tidak terealisasikan dan bahkan dialihkan ke program lain yang lebih mendatangkan profit. Namun seiring berjalannya waktu program CSR semakin diimplementasikan dengan baik. Bahkan tidak hanya BUMN yang diwajibkan untuk menjalankan program CSR, perusahaan swasta yang lainnya juga diwajibkan atas hal tersebut. Untuk itu, peneliti mengambil BUMN sebagai populasi penelitian ini.

Sampel adalah bagian dari jumlah dan karakteristik yang dimiliki oleh populasi tersebut (Sugiyono, 2012). Menurut website resmi BUMN yaitu www.bumn.go.id keseluruhan jumlah perusahaan BUMN yang telah diperbaharui pada 3 Januari 2017 lalu yaitu berjumlah 118 buah. Tidak semua perusahaan BUMN yang menjadi populasi penelitian tercatat pada Bursa Efek Indonesia. Dari hasil peelusuran melalui website resmi Bursa Efek Indonesia pada www.idx.co.id perusahaan BUMN yang listing di BEI berjumlah 20 buah perusahaan. Jadi, peneliti mengambil sampel pada BUMN yang hanya tercatat pada BEI saja. Tabel 1 menunjukkan nama-nama perusahaan yang dijadikan sampel.
Data yang digunakan pada penelitian ini adalah data skunder yaitu berupa laporan tahunan dan laporan keuangan perusahaan. Laporan tahunan didapat melalui website resmi masing-masing perusahaan dengan batas tahun 2014 dan 2015. Sedangkan laporan keuangan didapatkan melalui Bursa Efek Indonesia untuk tahun 2014 dan tahun 2015.

Sampel yang digunakan pada penelitian ini yaitu perusahaan BUMN yang terdaftar pada Bursa Efek Indonesia (BEI) berjumlah 20 perusahaan. Penentuan sampel diambil menggunakan teknik purposive sampling yaitu sampel yang diambil berdasarkan kriteria yang ditentukan dari peneliti.

Metode analisis yang digunakan pada penelitian ini yaitu menggunakan regresi data panel. Dimana data panel menrupakan penggabungan antara data cross section dengan time series. Cross section pada penelitian ini yaitu 20 perusahaan BUMN, sedangkan time series pada penelitian ini yaitu tahun 2014 dan 2015 . 
TABEL 1 DAFTAR SAMPEL

\begin{tabular}{clc}
\hline No & \multicolumn{1}{c}{ Nama Perusahaan } & Tanggal Daftar \\
\hline 1 & Adhi Karya (Persero) Tbk & 18-Mar-04 \\
2 & Aneka Tambang (Persero) Tbk & 27-Nov-97 \\
3 & Bank Negara Indonesia Tbk & 25-Nov-96 \\
4 & Bank Rakyat Indonesia (Persero) Tbk & 10-Nov-03 \\
5 & Bank Tabungan Negara (Persero) Tbk & 17-Dec-09 \\
6 & Bank Mandiri (Persero) Tbk & 14-Jul-03 \\
7 & Garuda Indonesia (Persero) Tbk & 11-Feb-11 \\
8 & Indofarma Tbk & 17-Apr-01 \\
9 & Jakarta International Hotels \& Development Tbk & 29-Feb-84 \\
10 & Jasa Marga Tbk & 12-Nov-07 \\
11 & Kimia Farma (Persero) Tbk & 04-Jul-01 \\
12 & Krakatau Steel (Persero) Tbk & 10-Nov-10 \\
13 & Perusahaan Gas Negara (Persero) Tbk & 15-Dec-03 \\
14 & Tambang Batubara Bukit Asam Tbk & 23-Dec-02 \\
15 & PT Semen Baturaja (Persero) Tbk & 28-Jun-13 \\
16 & Semen Indonesia (Persero) Tbk & 08-Jul-91 \\
17 & Timah (Persero) Tbk & 19-Oct-95 \\
18 & Telekomunikasi Indonesia (Persero) Tbk & 14-Nov-95 \\
19 & Wijaya Karya Tbk & 29-Oct-07 \\
20 & Waskita Karya (Persero) Tbk & 19-Dec-12 \\
\hline
\end{tabular}

Teknik pengambilan sampel yang dilakukan adalah purposive sampling. Yaitu teknik pengambilan sampel yang ditentukan sendiri oleh peneliti berdasarkan pertimbangan tertentu. Perusahaan bisa dijadikan sampel, apabila telah memenuhi suatu kriteria yang telah dibuat oleh peneliti.

Kriteria dalam pemilihan sampel sebagai berikut ;

- Perusahaan BUMN yang telah go public serta sudah terdaftar pada Bursa Efek Indonesia periode 2014 dan periode 2015.

- Tersedianya data laporan keuangan perusahaan periode 2014 dan periode 2015.

- Perusahaan sampel harus mengungkapkan CSR berturut-turut pada periode 2014 dan periode 2015 melalui annual report masing-masing perusahaan.

- Perusahaan tidak mengalami delisting dari BEI

\section{Jenis dan Sumber Data}

Jenis data yang digunakan dalam penelitian ini adalah data sekunder berupa dokumenter yaitu laporan keuangan perusahaan BUMN yang telah go public dan terdaftar di BEI pada periode 2014 dan 2015. Pengumpulan data dilakukan dengan penelusuran laporan keuangan atas nilai ROA dan NPM perusahaan, serta menelusuri biaya-biaya sosial yang dikeluarkan selama melakukan kegiatan CSR yang didapat dari analisis annual report masing-masing perusahaan.

Sumber data yang digunakan adalah data sekunder yaitu data yang diperoleh secara tidak langsung yaitu melalui website resmi BEI yaitu www.idx.co.id yang merupakan pusat dari referensi penelitian. Dari segi waktu pengumpulan data dalam penelitian ini tergolong ke dalam data panel yaitu kombinasi antara data silang tempat (cross section) dengan data runtun waktu (time series).

\section{Teknik Pengumpulan Data}

Teknik pengumpulan data pada penelitian ini yaitu studi dokumentasi terhadap laporan tahunan serta laporan 
keuangan perusahaan. Studi dokumenter merupakan proses mendapatkan dokumen-dokumen atau informasi-informasi penunjang penelitian kemudian dipelajari, ditelusuri, dan dianalisis kemudian dikumpulkan sehingga dapat diketahui hubungan antara karakteristik perusahaan dengan yang diamati dalam penelitian ini.

Selanjutnya melakukan penelusuran keuangan perusahaan sampel. Kegiatan penelusuran meliputi:

- Menghitung variabel profitabilitas (ROA \& NPM) masing-masing perusahaan sampel periode 2014 dan periode 2015. ROA \& NPM yang digunakan sebagai input data yang diolah oleh alat analisis berupa Eviews.

- Menelusuri item-item pengungkapan CSR pada laporan tahunan perusahaan sampel dengan pengungkapan CSR dibagi menjadi enam kategori, yakni :
a. Kinerja Ekonomi
b. Kinerja Lingkungan
c. Ketenagakerjaan
d. Hak Asasi Manusia
e. Masyarakat Sosial
f. Tanggung Jawab Produk

Masing-masing kategori memiliki beberapa item, dengan total item berkisar antara 63 sampai dengan 78 item.

\section{METODE ANALISIS DATA}

\section{Uji Asumsi Klasik}

Karena data yang digunakan adalah data sekunder, maka untuk menentukan ketepatan model perlu dilakukan pengujian atas beberapa asumsi klasik yang harus dipenuhi meliputi: uji normalitas, uji multikolinearitas, uji heterokendastisitas, dan uji autokorelasi. Namun dalam analisis deskrptif ini peneliti hanya menggunakan uji asumsi klasik berupa uji normalitas, uji multikolinearitas, dan uji heteroskedastisitas.

\section{Teknik Regresi Data Panel}

Model regresi panel adalah metode analisis data yang akan digunakan dalam penelitian ini. Regresi panel merupakan perpaduan antara data silang tempat (cross section) dengan data runtun waktu (time series). Aplikasi yang tepat dalam menggunakan teknik regresi panel adalah menggunakan aplikasi Eviews. Beberapa metode yang digunakan dalam mengestimasi model regresi data panel, yaitu pooling least square (Common Effect), pendekatan efek tetap (Fixed Effect), pendekatan efek random (Random Effect).

\section{Menentukan Model Terbaik}

Untuk menentukan model terbaik dari tiga pendekatan metode panel diatas yaitu dengan menggunakan tiga teknik estimasi model. Tiga teknik ini digunakan dalam regresi data panel untuk memperoleh model yang tepat. Berikut adalah pengujian yang digunakan:

\section{a. Chow Test}

Chow Test digunakan untuk membandingkan anatar pendekatan Common Effect dengan Fixed Effect. Dalam penelitian ini menggunakan program Eviews. Hipotesis yang dibentuk dalam Chow Test adalah sebagai berikut:

$\mathrm{H}_{0}$ : Model Common Effect

$\mathrm{H}_{1}$ : Model Fixed Effect

$\mathrm{H}_{0}$ ditolak jika $P$-Value lebih kecil dari a. Sebaliknya, $\mathrm{H}_{0}$ diterima jika $P$-Value lebih besar dari nilai a. Nilai a yang digunakan adalah $5 \%$.

b. Hausman Test

Hausman test menggunakan program yang serupa dengan Chow test yaitu program Eviews. Model Hausman Test digunakan untuk membandingkan pendekatan Random Effect dengan Fixed Effect. Hipotesis yang dibentuk dalam Hausman test adalah sebagai berikut:

$\mathrm{H}_{0}$ : Model Random Effect

$\mathrm{H}_{1}$ : Model Fixed Effect

$\mathrm{H}_{0}$ ditolak jika $P$-value lebih kecil dari nilai a. Sebaliknya, $\mathrm{H}_{0}$ diterima jika $P$ value lebih besar dari nilai a. Nilai a yang digunakan sebesar $5 \%$.

c. Langrangge Multiplier Test (LM Test) Yaitu dengan membandingkan model Common Effect dengan model Random 
Effect, pengujian ini dibentuk ke dalam Langrangge Multiplier Test (LM Test) menggunakan aplikasi Eviews sebagai berikut:

$\mathrm{H}_{0}=$ Model Common Effect

$\mathrm{H}_{1}=$ Model Random Effect

Kriteria penolakan $\mathrm{H}_{0}$ yaitu jika nilai Chi-Square Statistics $\left(\mathrm{X}^{2}\right)$ hitung $>$ ChiSquare Statistics $\left(\mathrm{X}^{2}\right)$ tabel atau nilai Prob Chi-Square Statistics $\left(\mathrm{X}^{2}\right)<\alpha$. Dengan nilai a yang digunakan adalah $5 \%$.

\section{HASIL DAN PEMBAHASAN}

Berdasarkan pengujian yang telah dilakukan pada Uji Chow Test, Uji Hausman Test, dan Uji LM Test telah didapat bahwasanya model terbaik untuk menjawab hipotesis pada variabel dependen Y1 adalah model Random Effect. Sementara untuk menjawab hipotesis pada variabel dependen Y2 adalah model Fixed Effect. Hasil pengujian hipotesis pada dependen Y1 dengan model Random Effect adalah sebagai berikut:

\section{TABEL 2 UJI RANDOM EFFECT}

Dependent Variable: Y1?

Method: Pooled EGLS (Cross-section random effects)

Date: 06/02/17 Time: 21:41

Sample: 12

Included observations: 2

Cross-sections included: 20

Total pool (balanced) observations: 40

Swamy and Arora estimator of component variances

\begin{tabular}{crrrr}
\hline \hline Variable & Coefficient & Std. Error & t-Statistic & Prob. \\
\hline \hline C & 0.024452 & 0.036923 & 0.662265 & 0.5124 \\
X1? & -0.002281 & 0.006197 & -0.368151 & 0.7151 \\
X2? & 0.001922 & 0.002026 & 0.948655 & 0.3497 \\
X3? & -0.004464 & 0.004011 & -1.112876 & 0.2738 \\
X4? & 0.007506 & 0.009282 & 0.808699 & 0.4245 \\
X5? & 0.026712 & 0.011335 & 2.356699 & 0.0245 \\
X6? & -0.005319 & 0.004837 & -1.099482 & 0.2795 \\
\hline \hline
\end{tabular}

Effects Specification

\begin{tabular}{lllr} 
& & S.D. & Rho \\
\hline \hline Cross-section random & & 0.051923 & 0.8368 \\
Idiosyncratic random & & 0.022933 & 0.1632 \\
\hline \hline & \multicolumn{2}{l}{ Weighted Statistics } & 0.011228 \\
& 0.272169 & Mean dependent var & 0.025789 \\
\hline \hline R-squared & 0.139836 & S.D. dependent var & 0.018879 \\
Adjusted R-squared & 0.023918 & Sum squared resid & 1.596998 \\
S.E. of regression & 2.056702 & Durbin-Watson stat & \\
F-statistic & 0.085631 & & \\
Prob(F-statistic) & & & \\
\hline \hline
\end{tabular}

\begin{tabular}{lllr}
\hline \hline & Unweighted Statistics & \\
\hline \hline R-squared & 0.049674 & Mean dependent var & 0.037665 \\
Sum squared resid & 0.131292 & Durbin-Watson stat & 0.229635 \\
\hline
\end{tabular}

Catatan. Hasil Olahan Eviews 9, Juni 2017. 
Suatu variabel bebas (X) dikatakan berpengaruh signifikan terhadap variabel terikatnya (Y) apabila nilai yang dihasilkan $<0,05$. Berdasarkan output yang ditampilkan pada Tabel 2 diatas, maka peneliti dapat menjawab hipotesis dari variabel Y1 sebagai berikut:

$\mathrm{H}_{1}$ : indikator kinerja ekonomi tidak memiliki pengaruh yang signifikan terhadap Return On Asset

$\mathrm{H}_{2}$ : indikator kinerja lingkungan tidak memiliki pengaruh yang signifikan terhadap Return On Asset

$\mathrm{H}_{3}$ : indikator ketenagakerjaan tidak memiliki pengaruh yang signifikan terhadap Return On Asset

$\mathrm{H}_{4}$ : indikator hak asasi manusia tidak memiliki pengaruh yang signifikan terhadap Return On Asset

\section{TABEL 3 UJI FIXED EFFECT}

Dependent Variable: Y2?

Method: Pooled Least Squares

Date: 06/03/17 Time: 09:03

Sample: 12

Included observations: 2

Cross-sections included: 20

Total pool (balanced) observations: 40

\begin{tabular}{crrrr}
\hline \hline Variable & Coefficient & Std. Error & t-Statistic & Prob. \\
\hline \hline C & 0.091717 & 0.058057 & 1.579780 & 0.1365 \\
X1? & 0.001540 & 0.009836 & 0.156595 & 0.8778 \\
X2? & 0.027807 & 0.003824 & 1.251662 & 0.0312 \\
X3? & -0.011357 & 0.006473 & -1.754519 & 0.1012 \\
X4? & 0.006176 & 0.015056 & 2.402720 & 0.3307 \\
X5? & -0.015864 & 0.017718 & 0.895370 & 0.3857 \\
X6? & -0.008003 & 0.007686 & -1.041270 & 0.3154 \\
\hline \hline
\end{tabular}

Effects Specification

Cross-section fixed (dummy variables)

\begin{tabular}{lllr}
\hline \hline R-squared & 0.971255 & Mean dependent var & 0.091390 \\
Adjusted R-squared & 0.919924 & S.D. dependent var & 0.118872 \\
S.E. of regression & 0.033638 & Akaike info criterion & -3.696137 \\
Sum squared resid & 0.015841 & Schwarz criterion & -2.598365 \\
Log likelihood & 99.92274 & Hannan-Quinn criter. & -3.299218 \\
F-statistic & 18.92150 & Durbin-Watson stat & 3.809524 \\
Prob(F-statistic) & 0.000000 & &
\end{tabular}


Suatu variabel bebas (X) dikatakan berpengaruh signifikan terhadap variabel terikatnya (Y) apabila nilai yang dihasilkan $<0,05$. Berdasarkan output yang ditampilkan pada Tabel 3 diatas, maka peneliti dapat menjawab hipotesis dari variabel Y2 sebagai berikut:

$\mathrm{H}_{7}$ : indikator kinerja ekonomi tidak memiliki pengaruh yang signifikan terhadap Net Profit Margin

$\mathrm{H}_{8}$ : indikator kinerja lingkungan memiliki pengaruh yang signifikan terhadap Net Profit Margin

$\mathrm{H}_{9}$ : indikator ketenagakerjaan tidak memiliki pengaruh yang signifikan terhadap Net Profit Margin

$\mathrm{H}_{10}$ : indikator hak asasi manusia tidak memiliki pengaruh yang signifikan terhadap Net Profit Margin

$\mathrm{H}_{11}$ : indikator masyarakat sosial tidak memiliki pengaruh yang signifikan terhadap Net Profit Margin

$\mathrm{H}_{13}$ : item-item pengungkapan CSR secara keseluruhan tidak memiliki pengaruh yang signifikan terhadap Net Profit Margin.

\section{SIMPULAN DAN SARAN}

\section{SIMPULAN}

Pengungkapan CSR pada perusahaan BUMN yng terdaftar di BEI dengan tahun teliti 2014 dan 2015 sudah mengungkapkan program CSR dengan baik di masing-masing laporan tahunan perusahaan walaupun dengan jumlah skor pengungkapan berbeda-beda setiap perusahaan.

Berdasarkan pada hasil penelitian yang diolah menggunakan aplikasi Eviews, dapat ditarik kesimpulan bahwa:

Pertama, dari enam indikator CSR dalam pengungkapan CSR, hanya terdapat satu indikator yang memiliki pengaruh yang signifikan terhadap Return On Asset yaitu indikator Masyarakat sosial. Sementara secara keseluruhan tidak terdapat pengaruh yang signifikan antara CSR terhadap Return On Asset (ROA).
Kedua, dari enam indikator CSR dalam pengungkapan CSR, hanya terdapat satu indikator yang memiliki pengaruh yang signifikan terhadap Net Profit Margin yaitu indikator kinerja lingkungan. Sementara secara keseluruhan tidak terdapat pengaruh yang signifikan antara CSR terhadap Net Profit Margin.

\section{SARAN}

Berdasarkan kajian yang sebelumnya yang sudah dibuat menjadi kesimpulan, maka dapat dikemukakan beberapa saran baik untuk kepentingan praktis maupun untuk pengembangan penelitian selanjutnya sebagai berikut:

1. Diharapkan bagi perusahaan BUMN untuk lebih memperhatikan kinerja ekonomi dan menyeimbangkannya bersama dengan profit yang perusahaan miliki.

2. Diharapkan bagi perusahaan BUMN untuk mampu melibatkan diri kedalam kinerja lingkungan serta menyeimbangkannya dengan profit yang perusahaan miliki.

3. Diharapkan bagi perusahaan BUMN untuk lebih memperhatikan tenaga kerja dan hubungan manajemen serta menyeimbangkannya dengan profit yang perusahaan miliki.

4. Diharapkan bagi perusahaan untuk lebih melindungi hak asasi manusia serta menyeimbangkannya dengan profit yang perusahaan miliki.

5. Diharapkan bagi perusahaan BUMN untuk lebih peduli terhadap masyarakat sosial serta menyeimbangkan kegiatan yang dilakukannya dengan profit yang perusahaan miliki.

Diharapkan bagi perusahaan BUMN untuk mampu memperhatikan tanggung jawab produk kepada pelanggan dan menyeimbangkannya dengan profit yang perusahaan miliki. 


\section{DAFTAR PUSTAKA}

Almar, M., Rachmawati, R., \& Murni, A. "Pengaruh Pengungkapan Corporate Social Responsibility (CSR) Terhadap Profitabilitas Perusahaan." Seminar Nasional Akuntansi \& Bisnis , 514-526, 2012.

Ghozali, I. Aplikasi Analisis Multivariate dengan Program IBM SPSS 20 (Edisi 6). Semarang: Badan Penerbit Uiversitas Diponegoro, 2012.

Harrison, Walter. T. Jr. et.al. Akuntansi Keuangan: International Financial Reporting Standars. Penerjemah Gina Gania. Jakarta: Erlangga, 2012. Murtaza, I. A., Akhtar, N., Ijaz, I., \& Sadiqa, A. "Impact of CSR Firm's Financial." International Review of Management and Business Research 3 (4), 1914-1927. 2014.

Pramana, I. G. A., \& Yadnyana, I. K. "Pengaruh Corporate Social Responsibility pada Kinerja Perusahaan Manufaktur." E-Jurnal Akuntansi Universitas Udayana Vol.16 No.3, 1964-1988, 2016.

Putra, A. S. "Pengaruh Corporate Social Responsibility Terhadap Profitabilitas Perusahaan." Jurnal Nominal 4(2), 88-110, 2015.
Putra, I. B. D., \& Wirakusuma, M. G. "Pengaruh Pengungkapan Corporate Social Responsibility pada Nilai Perusahaan dengan Profitabilitas sebagai Pemoderasi." E-Jurnal Akuntansi Universitas Udayana 13 (2), 461-475. 2015.

Rudito, B. CSR Corporate Social Responsibility. Sumatera Utara: Rekayasa Sains, 2013.

Samryn, L. M. Pengantar Akuntansi Mudah Membuat Jurnal dengan Pendektan Siklus Transaksi. Jakarta: PT Rajagrafindo Persada, 2014.

Sugiyono, P. D. Metode Penelitian Kombinasi Mixed Methods. Bandung: Alfabeta, 2012.

Susanto, A. B. Reputation Driven Corporate Social Responsibility. Jakarta: Erlangga, 2009.

Wulandari, A. A., Ramantha, I. W., \& Wirakusuma. M. G. Dampak Moderasi Profitabilitas Terhadap Pengaruh CSR pada Nilai Perusahaan Manufaktur. E-Jurnal Ekonomi dan Bisnis Universitas Udayana 5.7, 1889-1918, 2016.

www.bumn.go.id www.globalreporting.org www.idx.co.id 